\title{
PERSEPSI CALON GURU PAI TERHADAP KOMPETENSI 6C DALAM MENGHADAPI ERA 4.0
}

\author{
Ali Fikri ${ }^{1}$; Aulia Rahmawati ${ }^{2}$ Nur Hidayati $^{3}$ \\ ${ }^{1,2,3}$ Institut Agama Islam Negeri (IAIN) Kudus, Indonesia \\ Email Kontributor: \\ ${ }^{1}$ fikri@iainkudus.ac.id; ${ }^{2}$ aulia.rahma0106@gmail.com; \\ barukota348@gmail.com
}

\begin{abstract}
Abstrak
Di era 4.0 yang mana teknologi semakin berkembang pesat menyebabkan perubahan terhadap cara pandang dalam konsep pendidikan. Kompetensi yang dibutuhkan dalam dunia pendidikan juga mengalami perubahan. Hal tersebut berpengaruh terhadap kompetensi yang dimiliki calon guru. Mereka harus mempersiapkan, meningkatkan, serta terus mengasah kompetensi yang dimiliki agar mampu menghasilkan generasi berkualitas yang mampu menjawab tantangan di era 4.0 yang semakin canggih. Penelitian ini bertujuan untuk menjelaskan persepsi calon guru PAI, menjelaskan mengenai kompetensi $6 \mathrm{C}$ yang merupakan pembaharuan dalam kurikulum era 4.0 di mana dahulu dikenal dengan kompetensi 4C tetapi sekarang mendapat tambahan dua kompetensi baru oleh Mendikbud sehingga menjadi kompetensi 6C, serta tantangan yang dihadapi oleh calon guru PAI di era 4.0. Metode yang digunakan dalam penelitian ini yaitu metode deskriptif kualitatif dan studi literatur. Hasil dan pembahasan penelitian ini yaitu ditemukan bahwa: 1. Dari persepsi calon guru PAI banyak yang belum mengetahui mengenai kompetensi 6C yang sedang diusungkan oleh Mendikbud karena belum menjadi fokus di kalangan pendidik. 2. Calon pendidik berusaha mengasah kompetensi yang dimilikinya guna menghadapi era 4.0.
\end{abstract}

Kata Kunci : Persepsi, guru PAI, kompetensi, 6C, era 4.0.

\begin{abstract}
In the 4.0 era, technology was rapidly developing which caused changes in the perspective of education. The competencies needed in the world of education are also changing. This affects the competency of prospective teachers. They must prepare, improve, and continue to hone their competencies to be able to produce a quality generation that is able to answer the challenges in the current 4.0 era. This study aims to explain the perceptions of prospective PAI teachers, inform about $6 C$ competencies which is an update in the 4.0 era curriculum which was formerly known as 4C competencies but now gets two additional new competencies by the Minister of Education and Culture so that they become 6C competencies, as well as challenges faced by prospective PAI teachers in era 4.0. The method used in this research is descriptive qualitative method and literature study. The results and discussion of this research are found that: 1. From the perception of PAI teacher candidates many do not know about the $6 C$ competency being promoted by the Minister of Education and Culture because it has not been a focus among educators. 2. Prospective educators try to hone their competencies to face the 4.0 era.
\end{abstract}

Keywords: Perception, PAI teacher, competence, 6C, era 4.0. 


\section{A. PENDAHULUAN}

Perkembangan zaman yang semakin pesat di era 4.0 ini mempengaruhi perubahan dalam segala aspek kehidupan, salah satunya dalam dunia pendidikan. Pendidik menjadi tokoh utama dalam perubahan tersebut. Dalam hal ini, kesiapan seorang calon guru agar menjadi pendidik yang handal dan profesional dibutuhkan guna menghadapi berbagai permasalahan di era 4.0 yang semakin kompleks.

Untuk menjadi seorang pendidik yang handal dan profesional di era 4.0 beberapa persiapan perlu dilakukan oleh pendidik, diantaranya yaitu dengan meningkatkan kompetensi yang ada pada diri seorang pendidik. Yang mana hal tersebut dapat dipersiapkan ketika masih menjadi calon guru, dengan selalu meningkatkan dan mengasah kemampuannya sehingga ia mampu menjadi guru yang berkompeten dan siap menghadapi segala tantangan di era 4.0. Karena ditunjang dengan mutu dan kualitas guru yang baik, maka pendidikan akan berhasil dengan baik pula dari peningkatan mutu dan kualitas yang dimiliki oleh seorang pendidik tersebut.

Pendidik yang memiliki kompetensi dan mampu menghadapi segala tantangan dalam era perkembangan teknologi yang pesat ini akan mampu menghasilkan generasi peserta didik berkualitas yang sangat diperlukan agar siap, mampu bertahan dan bersaing dalam kompetisi di era 4.0. Dibutuhkan kerjasama oleh berbagai pihak agar berhasil menghadapi tantangan di era 4.0. Karena jika hanya berjalan sendiri, maka akan kesulitan untuk menghadapi perkembangan zaman tersebut. Kerjasama dan keintegrasian dapat dilakukan mulai dari peserta didik yang siap dan bersemangat menerima perubahan yang lebih pesat dan canggih di era 4.0 sehingga ia mampu mengembangkan inovasi yang kreatifitasnya dalam segala hal dan bidang. Lembaga pendidikan yang berusaha berkembang untuk maju dengan selalu meningkatkan mutu dan kualitas lembaga pendidikannya, serta pendidik yang berusaha meningkatkan dan mengembangkan pengetahuan, kompetensi, serta kualitas seorang pendidik agar mampu menciptakan suatu pembelajaran yang aktif, kreatif dan inovatif sehingga dapat menghasilkan generasi yang berkualitas.

Sebagai calon guru PAI, kompetensi pendidikan agama juga harus ditingkatkan, dalam Pendidikan Agama Islam (PAI) ilmu yang didapat mengenai keyakinan (aqidah), aturan (syari'ah), serta tata cara bersikap baik (berakhlakul karimah), tidak hanya menjadi suatu pengetahuan yang hanya diketahui saja, melainkan harus diamalkan dan dibiasakan dalam kehidupan sehari-hari. Sehingga calon guru PAI juga sebaiknya memiliki kompetensi 6C, dimana kompetensi $6 \mathrm{C}$ tersebut memang harus dimiliki dan dicapai oleh seorang pendidik. Baik seorang guru umum ataupun guru agama. Enam kompetensi tersebut yaitu: communication, collaboration, critical thinking, creativity, computational logic dan compassion. Di mana enam kompetensi tersebut, jika mampu dimiliki dan dikuasai oleh calon guru PAI, ia akan mampu menghadapi perkembangan zaman era 4.0. Meskipun pendidikan agama, keberadaannya tidak boleh diremehkan, pendidikan agama tersebut akan terus berkembang sesuai zaman.

Jika calon guru PAI mampu mengasah kompetensi yang dimiliki serta berusaha mencapai dan menerapkan kompetensi 6C, pendidikan agama Islam akan berkembang. Hal tersebut karena ketika menjadi seorang calon pendidik PAI, ia selalu mengasah kompetensinya serta terus belajar dan berusaha mencapai kompetensi 6C. Sehingga kelak ketika menjadi seorang guru PAI, ia akan siap menghadapi apapun tantangannya. 
Untuk memberitahukan kepada calon guru PAI apa yang harus dipersiapkan, kompetensi apa saja yang harus dimiliki, ditingkatkan dan diasah untuk menghadapi tantangan perkembangan pendidikan di era 4.0. Maka untuk itu, adanya penelitian ini akan membahas mengenai bagaimana persepsi calon guru PAI, menjelaskan lebih dalam mengenai kompetensi 6C yang diusung oleh Mendikbud, serta tantangan yang dihadapi oleh calon guru PAI di era 4.0. Sehingga dari rumusan tersebut, dapat menegetahui persepsi calon guru PAI, dapat mengetahui lebih dalam mengenai kompetensi 6C yang diusung oleh Mendikbud, serta mengetahui tantangan yang dihadapi oleh calon guru PAI di era 4.0.

\section{B. METODE PENELITIAN}

Penelitian_mengenai persepsi calon guru PAI terhadap kompetensi dalam menghadapi era 4.0 menggunakan pendekatan deskriptif kualitatif. Teknik pengumpulan data berupa angket terbuka dengan mengisi format google form yang di dalamnya terdapat pertanyaan-pertanyaan mengenai persepsi calon guru PAI terhadap kompetensi 6C di era 4.0 sekarang ini. Subjek dalam penelitian ini adalah calon guru Pendidikan Agama Islam (PAI) yang masih menempuh pendidikan di perguruan tinggi. Penelitian ini dimulai pada bulan April.

Selain angket terbuka, dalam pengumpulan data juga menggunakan studi literatur dari berbagai sumber pustaka. Seperti buku, artikel atau jurnal ilmiah, dan lainnya. Argumenargumen dari responden dan sumber pustaka lainnya kemudian dianalisis, dengan urutan analisis yaitu mengumpulkan dan memproses data, penyajian data, kemudian dilakukan suatu penarikan kesimpulan.

\section{HASIL DAN PEMBAHASAN}

Hasil dari angket yang telah diberikan kepada calon guru PAI ada yang sudah mengetahui tentang kompetensi $6 \mathrm{C}$, dan ada pula yang belum mengetahui tentang hal tersebut. Tetapi rata-rata belum mengetahui secara pasti dan mendalam mengenai kompetensi $6 \mathrm{C}$ yang merupakan keterampilan mengajar kurikulum 13 yang sebaiknya dimiliki dan diasah kembali oleh calon guru atau pendidik sekalipun. Karena jika para pendidik dan calon guru menguasai kompetensi tersebut, diharapkan akan menghasilkan sumber daya manusia yang siap untuk menghadapi kompetisi dalam perkembangan zaman yang semakin pesat. Maka dari itu, dalam penelitian ini akan dijelaskan kembali mengenai persepsi calon guru PAI terhadap kompetensi 6C di era 4.0.

\section{Persepsi Calon Guru PAI}

Persepsi berasal dari bahasa Inggris yaitu perception yang berarti menerima atau mengambil. Sedangkan dalam Kamus Besar Bahasa Indonesia, persepsi ialah tanggapan atau penerimaan langsung dari sesuatu. Proses seseorang mengetahui beberapa hal melalui panca inderanya (KBBI Daring). Adapun pengertian persepsi menurut Slamento dalam Handayani, persepsi adalah proses yang menyangkut masuknya pesan atau informasi dalam otak manusia secara terus menerus mengadakan hubungan dengan lingkungannya melalui indera (penglihatan, pendengaran, peraba, perasa dan penciuman) (Slamento dan Handayani, 2013:12). Sedangkan menurut Sarlito W. Sarwono, persepsi merupakan proses perolehan, penafsiran, pemilihan dan pengaturan informasi inderawi. Persepsi akan terjadi apabila mendapat stimulus dari luar kemudian diterima oleh indera (Rohmaul Listyana dan Yudi Hartono, 2015: 121). Josep A. De 
Vito berpendapat bahwa persepsi adalah proses dengan mana kita menjadi sadar akan banyaknya stimulus yang mempengaruhi indera (Josep A. De Vito, 1997:75). Jadi, dapat disimpulkan bahwa persepsi ialah proses penerimaan stimulus dari luar pribadi dan diterima oleh indera, bersifat otomatis sehingga setiap individu akan menghasilkan persepsi yang berbeda-beda. Persepsi juga sebagai cara pandang dan kepekaan individu mengenai lingkungannya.

Sedangkan calon guru Pendidikan Agama Islam (PAI), mengenai kata pendidikan sering dikatkan dengan kata tarbiyah yang berasal dari bahasa Arab berarti mendidik. Dalam kata tarbiyah terdapat tiga akar kata yaitu rabba-yarbuu berarti berkembang dan bertambah, rabiya berarti tumbuh dan berkembang, dan rabba-yarubbu berarti memperbaiki, mengatur, menjaga dan memperhatikan. Abdurrahman al-Nahlawi memahami kata tarbiyah dengan beberapa hal yaitu: 1) Pendidik yang sebenarnya ialah Allah swt. dan Dia lah yang memberi bakat serta potensi kepada manusia. 2) Pendidikan mempunyai tujuan, sasaran dan juga target. 3) Pendidikan dilakukan sesuai dengan sistematika yang telah ditentukan dan diharapkan akan tercapainya tujuan pendidikan. 4) Pendidik harus mengikuti syariat Islam untuk mencapai tujuan pendidikan.

Adanya guru agama Islam atau PAI penting adanya untuk menguatkan pendidikan karakter atau sikap peserta didik yang berakhlak mulia dimana dengan penguatan tersebut akan berdampak pada kehidupan siswa kelak sebagai generasi penerus bangsa yang bijaksana dalam menggunakan teknologi di era 4.0, yang mana jika guru PAI tidak ikut andil di dalam perkembangan teknologi yang canggih, maka tidak ada yang memberikan penguatan akhlak, moral dan sikap peserta didik selain orang tua yang juga menjadi pengawas dan pengontrol bagi anaknya (Farida Asyari, 2019: 217).

Seorang pendidik selain mengajarkan tentang pelajaran umum, diharapkan juga mampu memberikan pengajaran tentang akhlak sehingga akan menjadikan peserta didik yang cakap serta berakhlakul karimah. Namun untuk saat ini, masih ditemukan pendidik yang hanya memprioitaskan kecerdasan aqliyah dan kecerdasan jasmaniyah saja tanpa melihat aspek-aspek yang lain. Selain itu, pendidik pada zaman sekarang hanya sekedar menyampaikan pelajaran tanpa menyeimbangi dengan akhlak dan semata-mata mengharapkan gaji dari pemerintah atau swasta. Dampak negatif yang akan terjadi yaitu tawuran, penodongan, pemaksaan kehendak dan memperkosa (Muhammad Nasir, 2013:191-192).

Jadi, persepsi calon guru PAI merupakan pandangan atau cara pandang dari calon guru pendidikan agama Islam (PAI). Di dalam penelitian ini, para calon guru PAI masih menempuh pendidikan S1 disuatu perguruan tinggi. Menurut persepsi mereka mengenai kompetensi 6C baik jika dimiliki dan diterapkan oleh para pendidik karena banyak manfaat jika mampu menguasai kompetensi 6C tersebut. jika ke enam kompetensi tersebut mampu diterapkan oleh pendidik, maka pendidik tersebut akan berkompeten dalam mengajar serta berhasil mencetak generasi berkualitas yang akan mengisi perkembangan era 4.0.

\section{Kompetensi 6C}

Pendidikan menjadi salah satu aspek terpenting dalam segi kehidupan manusia serta mampu menjadi pendorong kemajuan suatu bangsa. Dalam dunia pendidikan, kompetensi sangat erat kaitannya akan potensi dan kemampuan yang dimiliki oleh seorang pendidik. Kompetensi pendidik yang tinggi dan profesional berpengaruh baik terhadap kemampuan pendidik dalam menyampaikan materi dengan mudah dan dapat diterima oleh siswanya. Hal 
tersebut selaras dengan yang dikatakan oleh Rusdin, (2017) bahwa kompetensi erat kaitannya dengan sebuah profesi keguruan, yang mana kompetensi profesional seorang guru dapat menjalankan tugas serta tanggung jawab yang diembannya dengan baik (Riskha Nur Fitriyah, 2019: 360).

Setiap pendidik ataupun calon pendidik harus menguasai kompetensi 6C. Karena dalam UU Republik Indonesia No. 14 tahun 2005 tentang guru dan dosen menyatakan bahwa kompetensi merupakan seperangkat pengetahuan, keterampilan, dan perilaku yang harus dimiliki, dihayati, dan dikuasai oleh guru dan dosen dalam melaksanakan tugas keprofesionalan. Jadi untuk mengembangkan keprofesionalan pendidik harus berusaha mencapai kompetensi 6C, agar menjadi guru yang berkompeten.

Sistem pendidikan di Indonesia diatur dengan kurikulum yang berkembang sesuai dengan perkembangan zaman, artinya kurikulum ini bersifat fleksibel. Kurikulum yang diterapkan di Indonesia saat ini ialah kurikulum 2013 atau disingkat menjadi kurtilas. Dalam kurtilas, seorang guru harus mempunyai kecakapan 4C yaitu Communication, Collaboration, Critical Thinking and Problem Solving, dan Creativity and Innovation. Berikut adalah penjelasannya:

\section{a. Communication (Komunikasi)}

Merupakan suatu usaha yang dilakukan oleh pendidik untuk mentransfer ilmu, pengetahuan serta pengalamannya kepada peserta didik baik dilakukan secara secara lisan maupun tulisan karena pada hakikatnya manusia ialah makhluk sosial, oleh karena itu kemampuan dalam berkomunikasi sangat diperlukan. Akan tetapi pada kenyataannya setiap orang memiliki kemampuan berkomunikasi yang berbeda-beda, dan bagi orang yang kurang cakap dalam berkomunikasi harus terus dilatih. Komunikasi yang baik juga memberikan dampak yang positif misalnya tidak terjadi salah faham atau salah persepsi. Dalam penyampaiannya tentu diperlukan beberapa teknik, yaitu:

1) Tidak berbelit-belit.

2) Jelas.

3) Lugas.

4) Memahami dan memperhatikan orang yang diajak bicara.

5) Menggunakan bahasa sesuai dengan kadar atau kemampuan yang diajak bicara.

6) Disertai dengan contoh nyata.

7) Sampaikan informasi dengan lembut supaya mudah diterima.

8) Memberikan umpan balik.

Komunikasi merupakan unsur penting dalam kegiatan pembelajaran. Karena dengan berkomunikasi akan mengetahui keadaan antara satu dengan yang lainnya. Di era 4.0 ini, berkomunikasi tidak ada sekat karena dunia sudah mengglobal.

b. Collaboration (Kolaborasi)

Merupakan kerjasama. Dalam pelaksanaan proses pendidikan tentu dibutuhkan kerjasama yang baik antara pendidik dan peserta didik guna untuk tercapainya tujuan pendidikan. Selain itu, collaboration juga dapat bermakna tanggungjawab dan fleksibel artinya mampu menempatkan diri serta tidak mencampuradukkan antara masalah pribadi dan sekolah. Maka dari itu apabila hubungan kerjasama antara pendidik dan peserta didik terjalin dengan baik maka tujuan pendidikan akan terwujud. 
c. Critical Thinking and Problem Solving (Berfikir kritis dan mampu memecahkan masalah)

Ketrampilan berfikir kritis berarti ia mampu menelaah dari analisis, melakukan evaluasi, serta mampu mengambil keputusan. Ketrampilan berfikir kritis tersebut sesuai dengan yang dikatakan oleh King, et al., yang mengungkapkan bahwa keterampilan berpikir kritis yaitu keterampilan dalam melakukan berbagai penilaian, analisis, evaluasi, rekonstruksi, serta pengambilan keputusan yang mengarah pada tindakan yang bersifat rasional dan logis (Elva Susanti dan Anggia Arista, 2019: 74).

Kemampuan berfikir kritis untuk memahami, mengamati serta memberi solusi terhadap suatu permasalahan. Hal ini perlu diperhatikan bagi pendidik maupun calon pendidik agar senantiasa berfikir kritis, agar tidak kebingungan ketika menghadapi suatu masalah.

d. Creativity and Innovation (Kreativitas dan Inovasi)

Dalam proses pembelajaran, seorang pendidik harus kreatif dan inovatif dalam menjalankan KBM atau kegiatan belajar mengajar. Pendidik yang kreatif dan inovatif tentu akan disenangi oleh peserta didik karena dalam pembelajaran disampaikan dengan berbagai cara dan selalu ada saja hal-hal yang baru sehingga membuat peserta didik tidak bosan serta memotivasi siswa untuk selalu belajar. Sehingga dengan adanya kompetensi kreatif, maka pembelajaran tidak akan jenuh, jika diterapkan akan mearik perhatian siswa agar selalu mengikuti pembelajaran dengan baik.

Selain point-point kecakapan diatas, Menteri Pendidikan Indonesia yaitu Bapak Nadiem Makarim menambahkan dua point kecakapan yang harus dikuasai oleh guru yaitu Computational Logic dan Compassion. Dua point tersebut harus dikuasai oleh guru agar dapat mengajar dengan maksimal.

\section{e. Computational logic}

Guru dituntut untuk memiliki kemampuan serta strategi dalam memecahkan masalah. Kemampuan tersebut dapat diimplementasikan pada saat proses belajar mengajar, misalnya ketika ada peserta didik yang hiperaktif saat pembelajaran berlangsung maka guru harus mempunyai strategi bagaimana caranya agar anak tersebut mau untuk mendengarkan pelajaran.

\section{f. Compassion}

Mencintai dan menjalankan profesinya dengan senang hati. Apabila sebuah pekerjaan dijalankan dengan senang hati maka akan memberikan dampak positif kepada orang lain, misalnya bertanggungjawab, memberikan teladan yang baik kepada peserta didik, memberikan motivasi untuk selalu belajar dan karena hal tersebut dapat memberikan dorongan semangat dalam belajar. Serta jika mengajar dengan rasa senang hati maka akan timbul rasa ikhlas. Sehingga jika pendidik mencintai profesinya, maka ia akan merasa tidak terbebani dengan kesulitan-kesulitan dalam mengajar.

Dari hasil angket yang diisi oleh para calon guru PAI, mengungkapkan bahwa karena belum mengetahui secara mendalam mengenai kompetensi $6 \mathrm{C}$ yang merupakan keterampilan mengajar di era 4.0 dalam pembaharuan kurikulum 2013, mereka tertarik untuk mencari tahu mengenai hal tersebut dan menggali potensi dalam dirinya agar mampu menguasai kompetensi 6C, mereka beranggapan bahwa dengan menguasai kompetensi tersebut, akan menjadi pendidik yang profesional serta mampu menghasilkan generasi peserta didik yang mampu bersaing dalam era perkembangan zaman yang semakin canggih. 


\section{Era 4.0}

Era 4.0 atau dikenal dengan era revolusi industri merupakan keadaan di mana teknologi berkembang sangat pesat. Hal tersebut disertai dengan perubahan yang signifikan dalam bidang sosial, ekonomi, budaya, dan pendidikan. Pendidikan di era 4.0 merupakan fenomena yang merespon kebutuhan masyarakat saat ini, dimana manusia dan mesin diselaraskan untuk mencari solusi, memecahkan masalah serta menemukan kemungkinan inovasi-inovasi yang baru. Inovasi teknologi dalam bidang pendidikan dapat mendukung pembelajaran dan mampu untuk meningkatkan kualitas sumber daya manusia untuk bersaing di kancah internasional. Untuk merealisasikan hal tersebut maka diperlukan lembaga-lembaga pendidikan yang berkualitas dan guru-guru yang kreatif dan inovatif dalam proses pembelajaran. Tentunya hal tersebut akan terwujud apabila didukung dengan infrastruktur yang memadai serta sarana prasarana pendidikan yang berbasis teknologi informasi dan komunikasi di era 4.0 (Tri Ani Hastuti, 2019: 877).

Pendidikan di masa yang akan datang harus mampu menghadapi era 4.0 dengan berbagai cara yang dapat dilakukan. Peserta didik harus mampu mengembangkan dan meningkatkan kompetensi diri. Sedangkan tantangan bagi guru adalah harus siap membantu peserta didik dalam mengembangkan kemampuan peserta didik (Supriatna, 2018).

Untuk menghadapi era 4.0 ini, guru dituntut memiliki kompetensi tinggi untuk menghasilkan peserta didik yang mampu menjawab tantangan revolusi industri 4.0. Menurut Qusthalani (2016), lima kompetensi yang harus dipersiapkan guru memasuki era revolusi industri 4.0 yaitu :

a. Educational competence yaitu kompetensi pembelajaran berbasis internet sebagai ketrampilan dasar. Setidaknya untuk menjadi guru yang profesional harus mampu menguasai teknologi yang diperlukan dalam pembelajaran. Oleh karena itu, hal tersebut harus dipersiapkan dengn terus belajar. Karena sekarang berada di zaman teknologi yang semakin canggih,

b. Competence for technological commercialization yaitu seorang guru harus memiliki kompetensi dalam menyiapkan peserta didik agar memiliki sikap enterpreneurship berbasis teknologi atas inovasi yang dihasilkan oleh peserta didik,

c. Competence in globalization yaitu guru harus siap dalam menghadapi berbagai macam budaya serta mampu dalam menyelesaikan persoalan pendidikan,

d. Competence in future strategies yaitu kompetensi untuk memprediksi dengan tepat mengenai kemungkinan-kemungkinan yang akan terjadi di masa depan dan strateginya dengan cara joint lecture, joint reserach, joint resource, staff mobility dan rotasi,

e. Conselor comptence yaitu kompetensi guru untuk memahami bahwa pendidikan di masa yang akan datang masalah yang akan dihadapi oleh peserta didik bukan hanya kesulitan dalam hal memahami materi ajar, tetapi juga terkait masalah psikologis akibat perkembangan zaman. Hal tersebut peran guru sebagai pembimbing diperlukan oleh siswa, untuk dapat mengarahkan, memberikan solusi dan saran terhadap masalah siswa, serta memberi motivasi siswa agar lebih baik kedepannya (Rahmatul Rahayuningrum dan Prihananti Septiana Sari, 70). 


\section{KESIMPULAN}

Seorang pendidik harus yang berkompeten dan mampu dalam segala bidang, untuk menjadi guru yang profesional. Mencapai hal tersebut, tidaklah mudah. Persiapanpun terus dilakukan ketika menjadi seorang calon guru, dibutuhkan juga keuletan, kerja keras, terus mengasah kemampuan dan meningkatkan kompetensi, serta usaha-usaha lain untuk menjadi pendidik yang mampu mencetak penerus bangsa unggul yang mampu menghadapi perkembangan zaman. Hasil dari angket yang telah diberikan kepada calon guru PAI ada yang sudah mengetahui tentang kompetensi $6 \mathrm{C}$, dan ada pula yang belum mengetahui tentang hal tersebut. Tetapi rata-rata belum mengetahui secara pasti dan mendalam mengenai kompetensi 6C yang merupakan keterampilan mengajar Kurikulum 2013 yang sebaiknya dimiliki dan diasah kembali oleh calon guru atau pendidik sekalipun. Karena jika para pendidik dan calon guru menguasai kompetensi tersebut, akan mampu menghasilkan sumber daya manusia yang siap guna, siap untuk menghadapi kompetisi dalam perkembangan zaman yang semakin pesat. Calon pendidik berusaha mengasah kompetensi yang dimilikinya guna menghadapi era 4.0. Kemudian hasil lain mengenai persepsi calon guru PAI banyak yang belum mengetahui mengenai kompetensi 6C yang sedang diusungkan oleh Mendikbud karena belum menjadi fokus dikalangan pendidik. Hasil lain yaitu, calon pendidik berusaha untuk mengasah kompetensi yang dimilikinya guna menghadapi era 4.0.

\section{DAFTAR PUSTAKA}

Asyari, Farida. (2019). Tantangan Guru PAI Memasuki Era Revolusi Industri 4.0 Dalam Meningkatkan Akhlaq Siswa di SMK Pancasila Kubu Raya Kalimantan Barat. Jurnal Muslim Heritage, 4(2).

De Vito, Josep A. (1997). Komunikasi Antar Manusia Edisi 5. Jakarta: Profesional Book.

Fitriyah, Riskha Nur. (2019). Pengembangan Kompetensi Guru di Era Revolusi Industri 4.0 Melalui Pendidikan dan Pelatihan.

Hastuti, Tri Ani. (2019). Implikasi Profesionalisme Guru untuk Pembelajaran Berorientasi Berfikir Tingkat Tinggi (HOTS) dalam Menghadapi Era Revolusi Industri 4.0.

Kamus Besar Bahasa Indonesia (KBBI) Daring, diakses pada 4 Maret, 2020, https://kbbi.kemdikbud.go.id.

Listyana, Rohmaul dan Yudi Hartono. (2015). Persepsi dan Sikap Masyarakat terhadap Penanggalan Jawa Dalam Penentuan Waktu Pernikahan (Studi Kasus Desa Jonggrang Kecamatan Barat Kabupaten Magetan Tahun 2013). Jurnal Agastya 5(1).

Nasir, Muhammad. (2013). Profesionalisme Guru Agama Islam (Sebuah Upaya Peningkatan Mutu Melalui LPTK). Dinamika Ilmu, 13 (2).

Rahayuningrum, Rahmatul dan Prihananti Septiana Sari, "Urgensi Peningkatan Kompetensi Guru dalam Menghadapi Tantangan di Era Revolusi Industri 4.0.

Slamento dan Handayani. (2013): Belajar dan Faktor-Faktor Mempengaruhi. Jakarta: Rineka Cipta. 